\title{
Development of integrated education management information system as the database of education budget policy formulation
}

\author{
${ }^{1}$ D.Rosana, ${ }^{2}$ Sukardiyono \\ ${ }^{1}$ Department of Natural Science Education, Yogyakarta State University, Indonesia \\ ${ }^{2}$ Department of Physics Education, Yogyakarta State University, Indonesia \\ *Corresponding Author's Email: danrosana@uny.ac.id
}

\begin{abstract}
The objective of this research is to produce the integrated education management information system as database for education budget policy formulation. The database that is precise, accurate, complete and taransparan is accessible to the public via the web in the android system, is a key element in any policy formulation and budget proposals in the field of education, that it can be used to reduce the corruption in the education area in a systematic which began drafting the state budget and regional budget. this research is a development that adapt the model Borg and Gall (1983). aiken's formula $v$ is used to analyze the instrument by the validator. The concept is to package products and services in one unit. To produce a product, a common cycle passed are: system specification, design, production, distribution, setup, use, maintenance, and renewal. The results of research is already made education management information system based on national education standards and geografic information system that has been tested is limited in some schools in the district region in indonesia. The policy recommendations of this research will support the government to modernize management of the education budgeting sector.
\end{abstract}

Keywords: integrated education management information system, education budget, policy recomendation

\section{INTRODUCTION}

The Teacher Law (No. 14/2005) introduced important changes to the employment conditions and requirements for the certification of teachers, aiming at improving education quality [1]. The Law on National Education (No.20/2003) and the Constitution Amendment III emphasize that all Indonesian citizens have the right to education; that the Government has an obligation to finance basic education without charging fees; and that the Government is mandated to allocate $20 \%$ of its expenditure on education. However, in 
practice rested in education is still often the target of corruption. Of the work of Indonesia Corruption Watch (ICW) corruption education budget reached 1.3 trillion during 2006 to 2015. Corruption is often at the beginning of the design and preparation of a budget plan that involves the executive and legeslatif. Education is central to the Indonesian Government's development agenda. In proving the effect of corruption indication on human development, Akcay [2] uses corruption data from three different sources for corruption index such as Corruption Perception Index, International Country Risk Guide's, and Corruption Index constructed by Kaufmann, et.all [3]; it reveals that there is negative but significant relationship of corruption index on human development

Education spending has increased significantly in the years since the economic crisis. In real terms, education spending doubled between 2000 and 2006. In 2007, spending on education was more than for any other sector, reaching an equivalent US\$14 billion equivalent, or more than 16 percent of total government expenditure. As a share of GDP (3.4 percent) this is comparable to other similar countries [1].. Some empirical studies on the role of corruption, Ventelou, [4] estimate that corruption act for $\$ 1$ results in economic loss for \$1.67. Mauro [5], Ades \& Di Tella [6], and Tanzi \& Davoodi [7] find the negative relationship between investment and corruption. Mauro [5] and Tanzi \& Davoodi [7] find the negative relationship between real gross domestic product per capita and corruption. The availability of integrated database on education that includes 8 educational standards, geographical conditions educational units, equalization educators, the condition of key infrastructure and supporting infrastructure, facilities, ease of access, and other information, is indispensable to the formulation of policies and the preparation of the budget for education, This database is designed to be accessed very easily using HP, iPad, Tabulet, or other media that is definitely owned by policy makers at the central government budget, local government, Regional Representatives Council and Parliament. 
The empirical evidence shows that the relationship between corruption and human resource quality is negative but significant; yet, the role of corruption on tax earning and misallocation of local government budget is positive and significant (Mauro [4]; Knack and Kneefer [8]; and, Dewi [9]). Anna [10] says that corruption causes the decrease on public service; besides, it causes a lame budget allocation on each sector. Chetwind et.al. [11] say that corruption reduces the composition balance of public budget allocation among education, health, and road infrastructure sectors; furthermore, it also affects economic growth in long term. Increased poverty and income inequalities constitute a further mechanism through which corruption could affect education. Several empirical studies show that higher corruption exacerbates income inequalities [Li et al. [12], Gupta et al. [13], Gymiah-Brempong [14], GymiahBrempong and de Camacho [15] and, Tebaldi and Mohan [16] and increases poverty Gupta et al. [13] and, Tebaldi and Mohan [16]. In a similar vein, Gupta et al. [13] state that corruption is likely to produce education inequalities.

Therefore, the aim of this study is to design the Integrated Education Management Information System database as policy making and budgeting in compliance with national standards for Web-based Geografic Information System (GIS) for android applications. In general, working Geographic Information System based on the integration components: hardware, software, data, people, and methods. This research is helpful to develop anticorruption system that is based on providing accurate data to minimize the budget stealth, especially in education. This is in accordance with the Ministry of National Education Strategic Plan for 2005-2009, that the purpose of the medium-term development of national education is number 12 , set the setting and management of education systems more efficient, productive, and democratic in good governance and accountability, and purpose number 14, that is, accelerate the eradication of corruption, collusion and nepotism 
to realize a clean and authoritative government. It is also supported by the enactment of the President of the Republic of Indonesia Number 96 Year 2014 About the Broadband Plan (broadband) Indonesia from 2014 to 2019 so that the ease of access becomes more assured.

The database that is precise, accurate, complete and taransparan as accessible to the public in the education management information systems, is crucial for the formulation of policies and the budget submission. The availability of integrated data base on education which includes eight standard education is necessary for policy formulation and budgeting. Therefore, the purpose of this research is to design a management information system based on eight standards of education as database equitable budgeting. The method used in the development of Education Management Information System is a system design concept of Product Service Systems (PSS) and the survey method as well as documentary analysis carried out for building a database of information education standards. The concept is to package products and services in one unit. Due to combine products and services, then there is a difference in perspective in terms of product design, designing services, and design a product-service system.

\section{MATERIALS AND METHODS}

The method used in the development of integrated education management information system with national education standards for Web-based Geografic Information System (GIS) is the design of the system with the Product Service Systems (PSS) and the survey method as well as documentary analysis conducted for the manufacture of information data base educational standards. Mobile GIS will be defined as the ability of mobile device to display geospatial data, and receive, process, and retrieve the GIS requests of mobile user. The most common framework for mobile GIS is to be considered as an extension to web-gis, where the gis requests of the mobile user are 
processed via internet web browser [17]. With the proliferation of mobile GIS applications, the emphasis is now laid on spatial data; data that have the characteristic location attribute in addition to other attributes they may have[18]. The concept is to package products and services in one unit. Due to combine products and services, then there is a difference in perspective in terms of designing a product, designing services and product-service system design. For some products, traversed a common cycle are: system specification, design, production, distribution, setup, use, maintenance, and renewal. Meanwhile for the service, the cycle is: the design concept, the determination of service devices, testing services, use, and implementation services. Education management information system based on national education standards and geografic information system, developed gradually through limited testing (sample District), the trial area (sample province), and Dissemination (sample National) by applying it to policy formulation and budgeting in collaboration with local government, provincial governments and the central government, so that legeslatif executives and can take the appropriate budget policies to support accurate data and easily access it any time when necessary.

The development of information and communication technology industries such as software istem integrated education management information in Indonesia is very relevant to the vision of Indonesia in 2025, as outlined in the National Long-Term Development Plan (RPJPN) from 2005 to 2025 and the Master Plan for the Acceleration and Expansion of Indonesian Economic Development (MP3EI) 2011-2025 , Because of budget management that is effective, efficient, accountable and transparent is an integral part of efforts to achieve the vision. In order to achieve this vision, it is necessary to strengthen national connectivity that is effective, efficient, and integrated, by integrating network management information istem integrated education is one component of the necessary ICT in development planning. 
This research also generates social interventions that could improve the character of the nation, particularly the anti-corruption culture. This is in accordance with the Ministry of National Education Strategic Plan for 2005-2009, that the purpose of the medium-term development of national education is number 12, set the setting and management of education systems more efficient, productive, and democratic in good governance and accountability, and purpose number 14 , that is, accelerate the eradication of corruption, collusion and nepotism to realize a clean and authoritative government. Efforts pengkuatan character of the nation, through the utilization of the complement system information management, integrated education is also considering the conditions and kerarifan local, because the data required adal; ah vary according to the geographical conditions in which the education unit is causing the utilization of possible charge materials and local resources in input data base in the information system. With the involvement of local human resources at the district level and the district in database development education, an increase in the role of human resources manager of the nation as a national industry and the formulation of policies that support behavioral change to respect national industrial products. For this study uses the Research and DevelopmentVarious types of teaching product development model generally uses a linear approach, Atwi Suparman [19]. The development process takes place step by step causally. In fact, a product development process will always pay attention to various supporting elements or elements that will be a process that is recursive. Starting from the consideration that the development assessment system approach will not be separated from the context of the management and organization of learning, the selected models of spiral, as referenced by Cennamo and Kalk [20]. In this spiral model known five phases of development, namely: (1) define, (2) design, (3) demonstrate, (4) develop, and (5) deliver. 
Developers will start the development from definition phase (which is the starting point of activity), headed out towards the phases of design, modeling, development, and presentation and in the process takes place in a spiral and the parties engage potential users, experts from the fields developed (subject matter experts), team members and instructors, and learners. At each phase of development the developer will always pay attention to the elements of the learning outcomes, activities, learners, assessment and evaluation. The development process will take place following the movement in the cycle of iterative (iterative cycles) of the vision definition vague moving towards products that are concretely proven effectiveness, as referenced by Dorsey, Goodrum, and Schwen [20] known with "the rapid prototyping process".

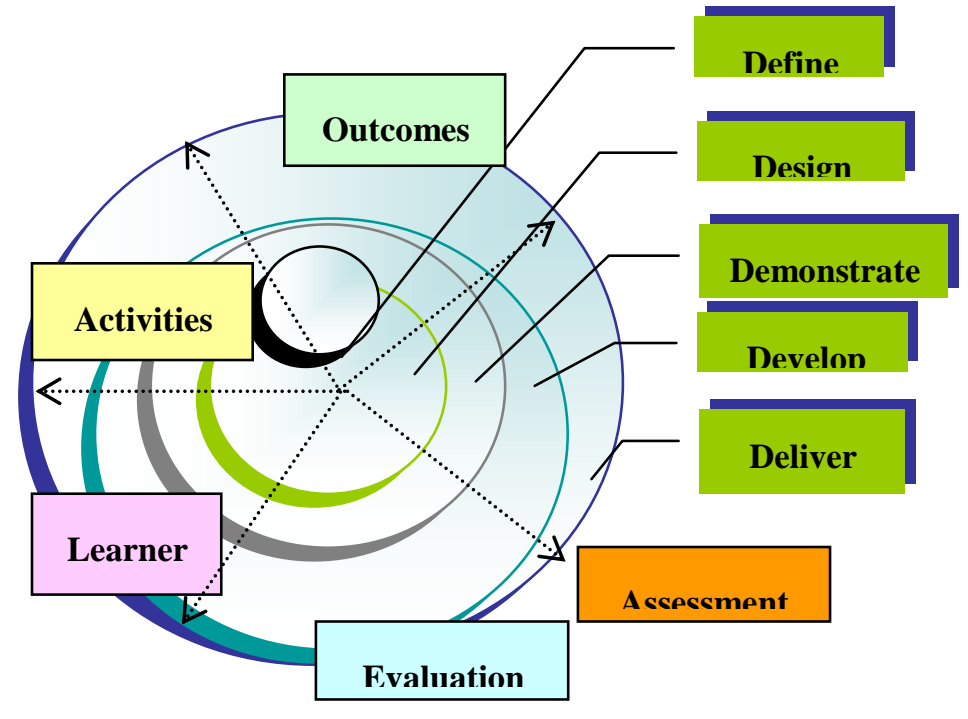

Figure 1. Five Phase Design Spiral Model of Teaching adapted from 'Five phases of instructional design' of Cennamo and Kalk [20]

In accordance with the general purpose of this research, designing an integrated education management information system web based geografic information system as a budget policy data base formulation for the reduction for potential corruption. Then the most appropriate method to achieve the goal of this research is the Research and Development (R \& D). According Gay [21], the R \& D approach is used in situations that can be described as follows. Its primary purpose is not to test the theory, but to develop 
and validate the devices that are used in the school in order to work effectively and ready to use. Borg and Gall [22] says "educational research and development (R \& D) is a process used to develop and validate educational product". From such understanding can be seen that research methode and development is a series of cyclical, that every step will be passed or do always refer to the results of the previous step, until finally acquired a new educational product . The products the-product was developed to meet the needs and based on defined specifications. R \& D to produce products that have been tested in the field and has been revised at the level of a certain effectiveness. Although the implementation of the $\mathrm{R} \& \mathrm{D}$ cycle is expensive, but produce quality products that comply with education requirements design.

\section{DISCUSSIONS OF FINDINGS}

The product development of education management information system based on national education standards and geografic information system (GIS) starts by testing its feasibility in drafting the education budget as a database of national education standards and efforts to reduce corruption in district region in Indonesia. The convergence of the rapidly progressing fields of wireless communication and lightweight hardware coupled with technologies like GIS and global positioning systems (GPS) has led to the emergence of a new field called mobile GIS [23]. The use of GIS has recently become popular (Lubenow \& Tolson [24]; Francica [25]; Hockstra \& Mattejat [26]; Nemeth [27]; Weigel \& Cao [28]. GIS is used to understand, analyze, and manage spatially distributed data mapped to a geographical region. In the early- to mid-1990s, the literature on GIS began to demonstrate concerns about the use of GIS in regard to its social and political impacts (Sheppard [29]; Schuurman [30]). Part of this concern had to do with the fact that gis 
advances an instrumental rationalist approach to decision-making, Elwood [31]. The design stage include designing the initial product. While the stages of development of validated products from ICT experts, education experts and users of the Department of Education. Validation is to obtain comments and suggestions both verbally and in writing in order to repair the initial draft of the product is then tested in a limited and widely.

The average value of the questionnaire responses in the form of scores given by ICT experts, education experts and users of the Department of Education shows validator feedback on the feasibility of the product with five categories as follows: 1 (not good); 2 (less good); 3 (fairly good); 4 (good); 5 (excellent).

Validation of products is divided into four components of the assessment. Components of the assessment shall include (1) the formulation of the development goals of the education management information system, (2) data, (3) display and analysis program, (4) the accuracy of the system. Each component has its own assessment aspects. The results of the validation of each component in the form of products that the average score is converted into value. Details of the results of product validation and conversion techniques scores into grades can be seen in the picture below.

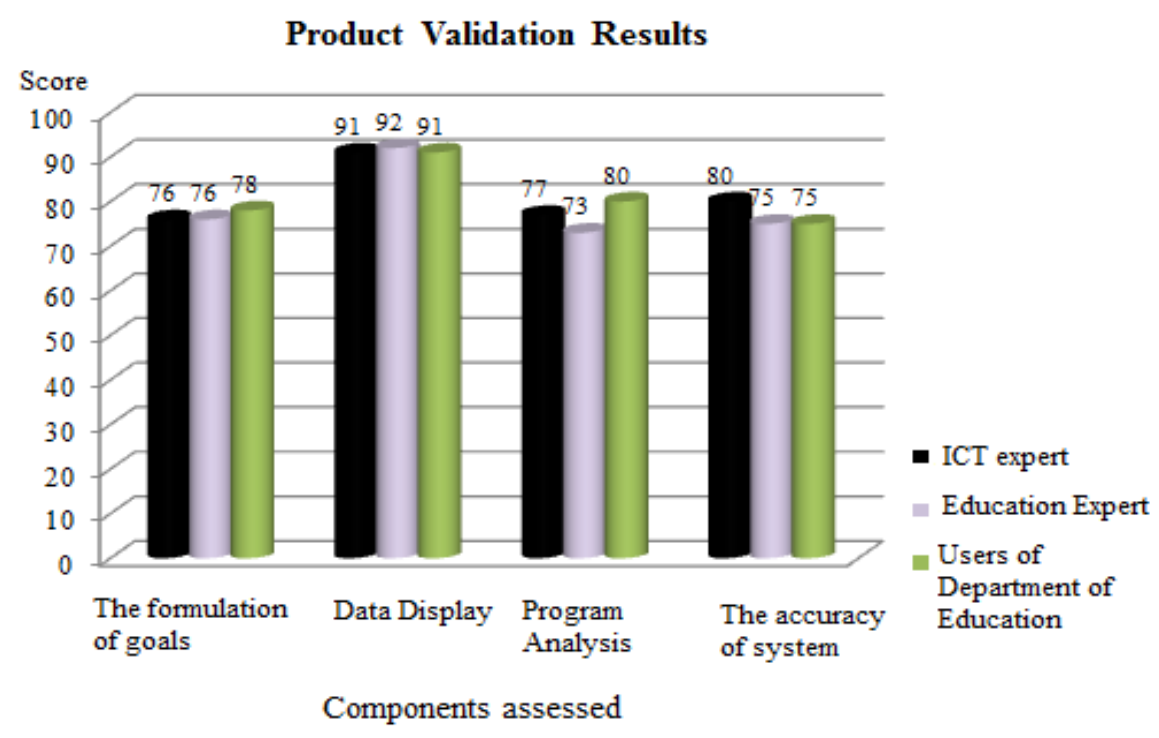


Furthermore, to determine more clearly the assessment results then average the results in the form of product validation validator assessment score is converted into a value scale of five and are shown in the following table!

Table 1. Results of Product Validation

\begin{tabular}{|c|c|c|c|c|}
\hline No & Validator & Assessed component & $\begin{array}{c}\text { Score } \\
\text { interval } \\
(5)\end{array}$ & Categories \\
\hline \multirow[t]{4}{*}{1} & $\begin{array}{l}\mathrm{ICT} \\
\text { experts }\end{array}$ & $\begin{array}{l}\text { The formulation of } \\
\text { goals }\end{array}$ & $\mathrm{B}$ & Good \\
\hline & & Data display & A & $\begin{array}{l}\text { Very } \\
\text { Good }\end{array}$ \\
\hline & & Program Analysis & B & Good \\
\hline & & $\begin{array}{l}\text { The accuracy of } \\
\text { system }\end{array}$ & A & $\begin{array}{l}\text { Very } \\
\text { Good }\end{array}$ \\
\hline \multirow[t]{4}{*}{2} & $\begin{array}{l}\text { Education } \\
\text { experts }\end{array}$ & $\begin{array}{l}\text { The formulation of } \\
\text { goals }\end{array}$ & B & Good \\
\hline & & Data display & A & $\begin{array}{l}\text { Very } \\
\text { Good }\end{array}$ \\
\hline & & Program Analysis & B & Good \\
\hline & & $\begin{array}{l}\text { The accuracy of } \\
\text { system }\end{array}$ & B & Good \\
\hline \multirow[t]{4}{*}{3} & $\begin{array}{l}\text { Users of } \\
\text { Education }\end{array}$ & $\begin{array}{l}\text { The formulation of } \\
\text { goals }\end{array}$ & B & Good \\
\hline & Department & Data display & A & $\begin{array}{l}\text { Very } \\
\text { Good }\end{array}$ \\
\hline & & Program Analysis & A & $\begin{array}{l}\text { Very } \\
\text { Good }\end{array}$ \\
\hline & & $\begin{array}{l}\text { The accuracy of } \\
\text { system }\end{array}$ & B & Good \\
\hline
\end{tabular}

Limited testing conducted at several schools in District Region in Indonesia. School election is purposive sampling by taking into account differences in the quality of schools (high, medium, low) and the ownership status of the school (public or private). Limited testing conducted after repair to an early draft of a product based on the results of validation of the validator. Limited trial aims to test the products developed keterpakaian. Besides, the purpose of limited testing done is to collect information used in order to improve the product. Information obtained in a limited test in the data collected on the advantages of the product as a management information system data base education budget. 
Data obtained from the product feasibility expediency observation sheet products were assessed by two observers. Assessment is done observers who are experienced and expert in the preparation of the education budget so that ratings given are completely objective and appropriate. Benefit assessment of products includes five aspects as follows: (1) infrastructure, (2) school-based management, (3) ease of access to transport, (4) the geographical position of the school and, (5) the budget system of the school.

The results can be seen through school mapping achievement scores given observer as the average value to determine the priority of assistance to a school. Reliability of the instrument observations were analyzed using the equation Borich and obtained the degree of alignment results between observer ratings of 93\%. According Borich [32], a good observation instrument is an instrument that has a value of $\mathrm{R}$ greater than or equal to $75 \%$ $(\geq 75 \%)$. Based on these results said that the observation instrument enforceability of learning "good" for use in the process of determining the priority schools that need assistance.

This research is already made education management information system based on national education standards and geografic information system that has been tested is limited in some schools in the district region in Indonesia. The policy recommendations of this research will support the government to modernize management of the education budgeting sector. Many development problems in the Indonesian context are characterized by scarcity and poor quality of data, approaches to problems constrained by jurisdictional and disciplinary boundaries, actors in government agencies who are paralyzed by perceived lack of power to share information with other stakeholders, and a public who consistently complain of closed and exclusive management processes. It is important to 
keep in mind that the application of web-distributed GIS is subject to issues associated with uneven access to technology and data.

This application of Education Informatiopn System based on GIS technology for public participation has potential to reach that segment of the population that has literacy, computer literacy, and access to computers and the internet only. If web-GIS is employed, careful thought should be given to what stakeholders may not be included in the process, and other means used to ensure their participation to reduce corruption. Corruption could also adversely affect education through its impact on public spending, more specifically public education expenditures. On the one hand, corruption may engender a substantial decrease in the resources allocated to education by affecting tax revenue and hence the volume of funds available to the government for allocation. Indeed, a considerable number of empirical studies provide evidence that revenues from tax collection are significantly lower in countries where corruption is widespread (Tanzi and Davoodi [34], Ghura [35], Johnson et al. [36], Friedman et al. [37], and Hwang [38]). Several empirical studies have provided evidence that corruption tends to go along with lower levels of education (Ades and Di Tella [39], Ali and Isse [40], Persson et al. [41], Cheung and Chan [42] and, Evrensel [43]). Furthermore, more educated individuals are expected to be less tolerant of corruption (Swamy et al. [44] and Mocan, [45])

The development of information and communication technology industry in Indonesia is very relevant to the vision of Indonesia in 2025, as outlined in the National Long-Term Development Plan (RPJPN) from 2005 to 2025 and the Master Plan for the Acceleration and Expansion of Indonesian Economic Development (MP3EI) 2011-2025. Because of budget management that is effective, efficient, accountable and transparent is an integral part of efforts to achieve the vision. In order to achieve this vision, it is necessary to 
strengthen national connectivity that is effective, efficient, and integrated, to integrate the education management information system network, which is one component of the necessary ICT in development planning and budgeting.

This research also generates social interventions that could improve the character of the nation, particularly the anti-corruption culture. This is in accordance with the Ministry of National Education Strategic Plan for 2005-2009, that the purpose of the Medium-term Development of National Education is Number 12, set the setting and management of education systems more efficient, productive, and democratic in good governance and accountability, and purpose number 14 , that is, accelerate the eradication of corruption, collusion and nepotism to realize a clean and authoritative government. Efforts to strengthen the character of the nation, through the use of education management information system is also considering the conditions and the local wisdom, because the data required adal; ah vary according to the geographical conditions in which the education unit is causing the utilization of possible charge materials and local resources in input data base in the information system. With the involvement of local human resources at the district level and the district in database development education, an increase in the role of human resources manager of the nation as a national industry and the formulation of policies that support behavioral change to respect national industrial products. Fershtman, et.all. [46] explore the relationship between social status, education, and economic growth and find that while social status plays an important role in the allocation of talent; its role may lead to decreased economic performance. Regarding education, higher income inequalities can lead to a lower political and popular support for redistributive policies, namely state funding of public education, which may weaken the efficiency of such policies, Benabou [47]. Empirically, many studies found higher income inequality to be 
associated with lower school enrollment and performance (Perotti [48], Flug et al. [49], Easterly [50], Mo [51], Checchi [52] and, Papagapitos and Riley [53]).

\section{RESULTS}

This application of Education Informatiopn System based on GIS technology for public participation has potential to reduce the potential education budget corruption. Corruption could also adversely affect education through its impact on public spending, more specifically public education expenditures. Because of budget management that is effective, efficient, accountable and transparent is an integral part of efforts to achieve the vision. In order to achieve this vision, it is necessary to strengthen national connectivity that is effective, efficient, and integrated, to integrate the education management information system network, which is one component of the necessary ICT in development planning and budgeting. The results of research is already made education management information system based on national education standards and geografic information system that has been tested is limited in some schools in the district region in Indonesia. The policy recommendations of this research will support the government to modernize management of the education budgeting sector.

\section{ACKNOWLEGMENT}

The authors thank to the Directorate of Research and Community Service, the Directorate General of Higher Education, Research and Technology Ministry had the Republic of Indonesia, due to the funding of Social and Humanities Research Scheme for this work. 


\section{REFERENCES}

1. World Bank. Bank Dunia dan pendidikan di Indonesia. http://www.worldbank.org/en/country /indonesia/brief/world-bank-and-education-inindonesia (2014)

2. Akcay, S. Corruption and Human Development. Cato Journal, Vol. 26, No. 1, 2006.

3. Kaufmann, D., Kraay, A., Mastruzzi, M. Governance Matters VII: Aggregate and Individual Governance Indicators, 1996-2007. The World Bank, Policy Research Working Paper Series n4654. Washington, DC: World Bank . 2008.

4. Ventelou, B. (2002). Corruption In a Model of Growth: Political Reputation, Competition and Shocks." Journal of Public Choice, hal. 23 - 40.

5. Mauro, Paolo. Corruption and Composition of Government Expenditure. Journal of Public Economics 69: 2, 63-79. (1998).

6. Ades, A., Di Tella, R. (1999), Rents, Competition and Corruption. The American Economic Review, 89, 982-993

7. Tanzi, V., Davoodi, H.R. (2001), Corruption, Growth, and Public Finances, in A.K. Jain (Ed.), The Political Economy of Corruption, chapter 5, 90-110, London: Routledge

8. Knack, S. and Kneefer, P. (1997) 'Does Social Capital Have an Economic Payoff? A Cross-country Investigation', Quarterly Journal of Economics 112(4): 1251-88

9. Dewi, S.N. P (2002). Pengaruh Korupsi Terhadap Pertumbuhan Investasi Domestik dan Foreign Direct Investment (11 Negara Asia Tahun 1995 - 2000). Tesis Pascasarjana Ilmu Ekonomi, Fakultas Ekonomi,Universitas Indonesia

10. Anna, K., (2003). Resolusi 58/4 tanggal 31 Oktober 2003, Majelis Umum PBB United Nation Convention Against Corruption (UNCAC), 9-11 Desember 2003 United Nation Office on Drugs and Crime (UNODC).

11. Chetwynd, E., Frances C., and Bertram, S., (2003). Corruption and Poverty: A Review of Recent Literature. Management Systems International

12. Li, H., Xu, L.C., Zou, H. (2000) Corruption, Income Distribution and Growth. Economics and Politics 12(2): 155-185

13. Gupta, Davoodi, and Tiongson. (2002). Corruption and the Provision of Health Care and Education Services In Governance, Corruption, and Economic Performance. The Journal of Government Financial Management, Volume 5, No. 2.

14. Gyimah-Brempong, K., Traynor, T. (1999) Political Instability, Investment, and Economic Growth in Sub-Saharan Africa. Journal of African Economies 8 (1): 52-86

15. Gyimah-Brempong, K., de Camacho, S.M. (2006), Corruption, Growth, and Income Distribution: Are there Regional Differences? Economics of Governance, 7, 245-269.

16. Tebaldi, E., Mohan, R. (2010), Institutions and Poverty. Journal of Development Studies, 46, 1047- 1066

17. Asmaa Ahmed Hussein, Elkhedr Hassan Eibrahim \& Aziza Asem. Mobile geographic information systems: a Case study on mansoura university, Egypt. International journal of computer science \& information technology (IJCSIT) Vol 3, No 6, 173-181. (2011).

18. Jekkin.D.Shah. Semantic Query Cashing in Mobile Environments. Computer Science and Electrical Engineering Journal, Vol. 12, 12-19. (2009).

19. Suparman, Atwi. 2001. Desain Intruksional. Jakarta: Pengembangan. Aktivitas Intruksional, Dirjendikti, Depdiknas 
20. Dorsey, L., Goodrum, D., \& Schwen, T. (1997). Rapid collaborative prototyping as an instructional development paradigm. In C. Dills \& A. Romiszowski (Eds.), Instructional Development Paradigms. Englewood Cliffs, NJ: Educational Technology Publications.

21. Gay, L.R. (1991). Educational Evaluation and Measurement; Competencies for Analysi,s and Application Second edition. New York: Macmillan Publishing Compan

22. Borg and Gall (1983). Educational Research, An Introducfioz. New York and London. Longman Inc.

23. Scholtz, J., Metrics for evaluating human information interaction systems. Interacting with Computers Journal. 18(4): 507-52. (2006)

24. Lubenow, A. \& Tolson, K. (2001). GIS technology helps pinpoint patients. Health Management Technology, v 222 No.1, p.54-55.

25. Francica, J. (2000). Location analysis tools help Starbucks brew up new ideas. Business Geographics, Vol. 8, No. 8, p. 32-33.

26. Hockstra, D. \& Mattejat, P. (2002). Manage drainage infrastructure. Public Works, Vol. 133, No. 5, p.170-171.

27. Nemeth, D. (2001). GIS shows how data becomes a vital corporate asset. Pipeline \& Gas Journal, Vol. 228, No. 3, p. 41- 43.

28. Weigel, D. \& Cao, B. (1999). Applying GIS and OR techniques to solve sears technician-dispatching and home-delivery problems. Interfaces, Vol. 29, No. 1, p.112130.

29. Sheppard, E. (2005) Knowledge Production through Critical GIS: Genealogy and Prospects. Cartographica, 40(4): 5-21.

30. Schuurman, N. (2006) Formalization Matters: Critical GIS and Ontology Research. Annals of the Association of American Geographers, 96(4): 726-739.

31. Elwood, S. A. (2002) GIS use in community planning: a multidimensional analysis of empowerment. Environmental and Planning A, 34(5): 905-922.

32. Borich, Gary D. Effective Teaching Methods: Research-based Practice. Upper Saddle River, N.J: Pearson Merrill/Prentice Hall, 2007. Print.

33. Borg, W. R., \& Gall, M. D. (1989). Educational research. New York: Longman.

34. Tanzi, V., Davoodi, H.R. (2001), Corruption, Growth, and Public Finances, in A.K. Jain (Ed.), The Political Economy of Corruption, chapter 5, 90-110, London: Routledge.

35. Ghura, D. (1998), Tax Revenue in Sub-Saharan Africa: Effects of Economic Policies and Corruption. IMF Working Paper, African Department, WP/98/135.

36. Johnson, S., Kaufmann, D., Zoido-Lobaton, P. (1999), Corruption, Public Finances, and the Unofficial Economy. The World Bank, Policy Research Working Paper n ${ }^{\circ} 2169$. Washington, DC: World Bank.

37. Fershtman, C., Murphy, K. M., \&Weiss, Y. (1996). Social Status, Education, and Growth. Journal of Political Economy, 104 (1), 108-32.

38. Hwang, J. (2002), A Note on the Relationship between Corruption and Government Revenue. Journal of Economic Development, 27, 161-178.

39. Ades, A., Di Tella, R. (1999), Rents, Competition and Corruption. The American Economic Review, 89, 982-993.

40. Ali, M. A., Isse, H.S. (2003), Determinants of Economic Corruption: A CrossCountry Comparison. Cato Journal, 22, 449-466

41. Persson, T., Tabellini, G., Trebbi, F. (2003), Electoral Rules and Corruption. Journal of the European Economic Association, 1, 958-989.

42. Cheung, H.Y., Chan, A.W.H. (2008), Corruption across Countries: Impacts from Education and Cultural Dimensions. The Social Science Journal, 45, 223-239. 
43. Evrensel, Ayşe Y. (2010), Institutional and Economic Determinants of Corruption: a Cross-section Analysis. Applied Economics Letters, 17, 551-554.

44. Swamy, A., Knack, S., Lee, Y., Azfar, O. (2001), Gender and Corruption. Journal of Development Economics, 64, 25-55.

45. Mocan, N. (2004), What Determines Corruption? International Evidence from Micro Data. NBER Working Paper $\mathrm{n}^{\circ} 10460$.

46. Fershtman, C., Murphy, K.M. and Y. Weiss 1996. Social Status, Education and Growth. Journal of Political Economy, 104, 108-132.

47. Benabou, R. (2000), Unequal Societies: Income Distribution and the Social Contract. The American Economic Review, 90, 96-129.

48. Perotti, R. (1996), Growth, Income Distribution, and Democracy: What the Data Say. Journal of Economic Growth, 1, 149-187.

49. Flug, K., Spilimbergo, A., Wachtenheim, E. (1998), Investment in Education: Do Economic Volatility and Credit Constraints Matter? Journal of Development Economics, 55, 465-481.

50. Easterly, W., Rebelo, S. (1993), Fiscal Policy and Economic Growth: An empirical investigation. Journal of Monetary Economics, 32, 417-458

51. Mo, P. H. (2001), Corruption and Economic Growth. Journal of Comparative Economics, 29, 66-79

52. Checchi, D. (2003), Inequality in Incomes and Access to Education: A Cross-country Analysis (1960- 95). LABOUR, 17, 153-201.

53. Papagapitos, A., Riley, R. (2009), Social Trust and Human Capital Formation. Economics Letters, 102, 158-160. 